\title{
Study of Digitalized Hostel Management System
}

\author{
Kartik Chaudhri, Riddhi Kevat \\ U.G. Scholar, Vishwakarma Government Engineering Collage, Chandkheda, Gujarat, India
}

\begin{abstract}
Article Info

Volume 7, Issue 2

Page Number: 366-371

Publication Issue :

March-April-2021

Article History

Accepted : 15 April 2021

Published : 22 April 2021

"eHostel" is an android application to automate the manual hostel management system of particular hostel associated with collage. It solves the important problems like room allocation, fee and fee receipt management, student management, complaint management, maintain visitor records, student leave management, and notice board. This application provides some additional facilities like secure user authentication, digital hostel pass, live notification, important form updates, user profile management.

Keywords: Room Allotment, Hostel Management
\end{abstract}

\section{INTRODUCTION}

"eHostel" is an android application to automate the manual hostel management process of particular hostel associated with collage. It solves the important problems like room allocation, fee and fee receipt management, student management, complaint management, maintain visitor records, student leave management, and notice board. Students are able to apply for hostel admission, view their room allocation details, view notice board, upload fee receipts, discuss complaint(s) to the warden, and create leave request, maintain in-out records also they get real time notification updates regarding the request they've made as well the updates conveyed from warden. The warden/faculty allocates room to particular students in real-time and, respond to particular leave request, fees verification, provide approval on digital hostel pass, also faculties can check the admission status of particular student, manage membership and respond to students complaint. Faculty can fulfil these tasks through their web based dashboard. The hostel gatekeeper are able to maintain the visitor entry day to day by scanning the Barcode for the visitor student. Faculty can view these activity anytime from their associated interface. The administrator/rector has all the major rights like to check admission status of student, room allocation of student, allocation of faculty(s) for the role of warden or hostel in charge Only Faculty and Administrator has web based dashboard for their office use. This application and web portal can be accessible from anywhere but they're used with specific rules and regulation made by the institute. This android application uses latest technologies like firebase cloud messaging for live notification and updates, REST API to access the database, PHP to provide web based dashboard, MySQL database to store data from all of the users and Barcode library to generate unique Barcode for student. 


\section{LITERATURE REVIEW}

In [1] proposed the web version of a hostel management system and integration of RFID system for gate pass purpose. This web interface is create using PHP-MySQL technology. It reduces the efforts made by the hostel chief and hostel proprietor while managing the hostel. It removes the pen and paper idea which is being utilized by us from before times. This system have Administrator, Warden and Student module, each have their different dashboards and roles. The created framework gives solution for manual hostel administration issues and further more gives data, for example, hostel data, student data, hostel room data. The administrators of this system are able to send notifications or notices to student through email system. It is secure online website accessible anywhere on the globe. They proposed the use of RFID tags for tracking purpose of student. RFID tags are given to student while hostel registration, so administrators can track the student activity from single dashboard.

In [2] a web portal for Hostel management system is proposed. It has major modules as student information, automatic bill calculation and room allocation. Student and Administrator have different dashboards. For taking seat into hostel, the student must have to register his/her detail on to the portal. Then the administrator will allot the room no., along with assets like chair, table and bed.

In [3] a web portal for Hostel management system is proposed, this web portal is developed in ASP.NET and SQL server technology. This system has three actors as Administrator, Hostel clerk and Student. This system provides facilities like Student driven hostel registration, Invoice generation and printing, Automatic due calculation and notification, student hostel clearance management etc.
Online Gate Pass Application Form for Hostel Students has been proposed in [4]. Gate Pass management system is the software application used to manage entry/exit of the students on short term and long-term leave. The gate pass is approved by HOD, Hostel warden or Hostel Manager and issued by the Hostel Warden. In this system the Student ask a request for entry or leave by filling the different details. The higher authority verify the details from the database, if valid then permission is granted or denied. The respected student is notified by email about his/her confirmation before time. The scope of the system is to record the details and activities of the students. Purpose of system is "Paper Saving Idea" by the use of technology.

In [7] Personality based Hostel Allocation System is demonstrated in that the students are allocated to rooms based on their temperaments, they uses First Come, First Serve approach for student registration, while registration system will ask few questions, served student has to answer them, their answers are then recorded into database through web portal. The approach of student selection is automatic and adopted from Eric Jorgenson's open four temperament scale test, which is used to develop sorting algorithm which is judiciously detects and allocate students to available rooms within hostel accommodation. This system is web based made up from PHP and MySQL technology. This system consist the implementation of above described algorithm which process the personality based on their answer given by students to the questions and sorts the student according to their personality and allocates the room only. The allocation of bed space and other hostel facilities is not included in this algorithm.

In [5] a single user and desktop based hostel management software is demonstrated. It is made up using Micorosoft's Visual Basic and it consumes SQL 
Server as backend. It has only user known as Administrator. It performs Student Management, Maintains IN-OUT records, Hostel Management an Report generation.

In [6] Biometric Authentication based Hostel management system is demonstrated. Security within the hostel is one of the foremost repetitive issues. To keep up day by day attendance verification is sophisticated and time consuming system for the hostel management. Within the existing system wardens are manually, maintain the attendance for hostel students. This paper deals with, avoid of an entire problem in hostel management system together with this monitoring system also proposed. This system has only one user as administrator, which can be college principal or warden. Biometric system is used to accommodate a large number of students within the hostel. This system makes automatically to monitor the entry and exit of students from hostel and offers alert SMS to parents for their safety.

In [8] Barcode Based student In-Out system is demonstrated, Student in-out system play significant role in order to justify in-out entry of a student in a college as overall. Unfortunately, there is no automated entry exit record keeping application available in colleges. There is a need for a tool to systematically keep the students entry exit record due to increasing number of college students. This system will help the Gatekeepers in college to avoid maintaining the registry book. This project uses a barcode scanner. B.B.S.I.O.S (Barcode Based Student In-Out System) uses Barcode scanner to take the entry exit record of students entering the college campus. Each student's ID card will have a barcode at the back side of it. This barcode contains unique data of the student such as student id. Student will scan their barcode at the gate so that the student cannot cheat. The display screen will show the entry exit record of the particular student after scanning his/her barcode. Gatekeeper and administrator will only have access to the system with their respective login ID's and passwords.

In [9] Mobile application named as E.H.R.A (Enhanced Hostel Registration Application) is demonstrated, The objective of this project is to develop android application with data storage system for hostel registration process in higher learning institution. Another objective is to promote green computing environment in higher learning institution by reducing the usage of paper in hostel registration system. In developing EHRA, the type of methodology to be used is Rapid Application Development (RAD). By applying RAD in the development process, there are four main phases: requirement analysis and system designing, project prototyping, system testing and execution. As the result, EHRA is designed with a few features such as room tracking, student's information tracking, add roommate and data storage. EHRA has two users as Management (Administrator) and Students. Administrator has Control of the system, Administrator can check for room availability, Register student for hostel and allocate room to that student. Student has to provide their details to Administrator for hostel registration. EHRA mobile application is built using Android. It consumes PHP to access data from MySQL database and display the results in HTML form, which is loaded back to android application.

A Survey on Android Based Hostel Security System Using $Q R$ code has been proposed in [10]. In the proposed system the admin will assign a $\mathrm{QR}$ code to the student. Student scans the Hostel QR Code For attendance at Entry/Exit using android phone. The Student can rise Night out request as well as raise Cleaning Issue to the warden. The warden can monitor the student records and daily roll call list. 
The main task of the warden is to view the students issue and take the proper action on it. Assigning the rooms to the students is also done by the warden itself. Warden uses Android App to monitor Student activity and provides responses to the student through this app. System Administrator uses web application for Registration of student an provide QR code to them. This System uses Android Application, Web Server and MySQL server.

In [11] A cloud-based, smart notice delivery system using OCR (Optical Character Recognition) has been proposed. The project is based on to digitalize the notice delivery mechanism, in a smart and efficient way, by using various cloud services provided by firebase. The basic idea of this work was to get the daily updated of the university on time, and we need to keep track of all the notice boards, almost daily. Sometimes due to Notice Boards located in different places there have been issues in past when one notice was displayed on the boards where such notices were not displayed usually and it creates problems for students. This project is for the notice delivery system and it is mainly targeted for the college students and faculties. To deliver public notices, on the go, directly to the user's device, is the main purpose to deal with. This project is useful for the college administration and as well as to the students. The purpose of the smart notice delivery system is to efficiently deliver notices and to build a convenient \& easy-to-use mobile application for students, usually navigate notice boards for daily updates. The whole mechanism is based on a NoSQL database, mainly FireStore database, with its notices storage and notification delivery functions. Moreover, we target to provide an impressive user experience along with the enhanced device capabilities.

Online Hostel management has been proposed in [12]. The main goal of this system is to increase Quality of Education system. The hostel management gives on idea about how the student's details, room allocation, mess bill are maintained in the particular concern. The hostel management system also includes some special features. The administration has the unique identity for each members as well as student details. The stock management has also held by mess expenditure, the mess expenditure that uses to calculate the mess bills of each of the students. The modules of this project are student details, attendance details, room details, mess modules.

The mobile based android application to manage student complaints has been proposed in [13]. The objective of this project is to develop android application for managing the complaints and enquiry. Students can fire a complaint from the mobile Application, the management is notified about a complaint. System reduces manual work for management System also provide feature of feedback. The methodology used to develop mobile app is Mobile Application Development Life Cycle (MADLC).The System Usability Scale (SUS) is used to measure the effectiveness of mobile application.

\section{RELATED WORK}

Presently many institutes has their own hostel management system according to their need. But these system contains many limitations, limitations like does not have remote access, only limited modules, does not use latest technologies etc. due to these limitations there is need of such application which overcome from this problems.

In this document, the proposed system is based on Android and has web portal for the institute authorities. Due to mobile application, the user can carry and access the system anywhere around the globe using their cell phone. 


\section{EFFICIENT SYSTEM}

R. K. Bista and A. J. Karki, of "Hostel Management System" [1] have demonstrated a Web based framework which is purely suitable for the hostel attached with Government Institutions. They developed different actors with their associated operations, as well as included RFID system based gate pass system. This system uses open source technologies for web portal development.

Poojashree and A. Murthy, of "Online Hostel Management"[3] have demonstrated a web based portal for hostel management system. It has two main actor as clerk and student. This system covers all the necessary tasks which are necessary and should be there in a Hostel management system. Sample Screenshot is shown in figure 1 below.

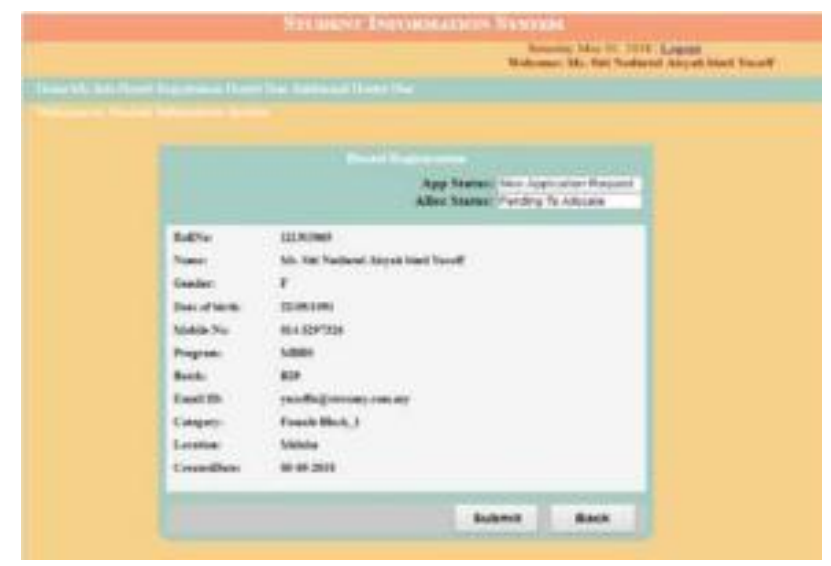

Figure 1. Clerk Page of "Online Hostel Management"

The Comparison of different system is described below in Table 1 based on the factors like features, actors and the limitations of particular system

\section{TABLE I}

COMPARISON OF DIFFERENT SYSTEMS

\begin{tabular}{|l|l|l|l|}
\hline \multicolumn{1}{|c|}{ Citation } & \multicolumn{1}{c|}{ Features } & \multicolumn{1}{c|}{ Actors } & Limitations \\
\hline (R. K. Bista & - RFID tags to & - & - Not \\
\&A. J. Karki) & track students & Adminis- & Accessible \\
{$[1]$} & - RFID based & trator & without \\
& gate pass & - Warden & internet. \\
& - User friendly & - Student & - Lack of \\
& Interface & & Modules \\
\hline
\end{tabular}

\begin{tabular}{|c|c|c|c|}
\hline & $\begin{array}{l}\text { - Easily } \\
\text { Accessible } \\
\text { through } \\
\text { internet }\end{array}$ & & $\begin{array}{l}\text { like } \\
\text { Attendance } \\
\text { \& leave } \\
\text { managemen } \\
\mathrm{t} \\
\text { - does not } \\
\text { have feature } \\
\text { of student } \\
\text { pass out. }\end{array}$ \\
\hline $\begin{array}{l}\text { (Poojashree } \\
\text { and A. } \\
\text { Murthy)[3] }\end{array}$ & $\begin{array}{l}\text { - Easily } \\
\text { Accessible } \\
\text { through } \\
\text { internet } \\
\text { - Invoice } \\
\text { Generation } \\
\text { - Student } \\
\text { Attendance } \\
\text { facility } \\
\text { - Student } \\
\text { Pass out } \\
\text { facility } \\
\text { - User friendly } \\
\text { UI }\end{array}$ & $\begin{array}{l}\text { - Student } \\
\text { - Clerk }\end{array}$ & $\begin{array}{l}\text { - Not } \\
\text { Accessible } \\
\text { without } \\
\text { internet. }\end{array}$ \\
\hline $\begin{array}{l}\text { (U. Elakkiya } \\
\text { and P. } \\
\text { Nirmala } \\
\text { Priyadarshini } \\
\text { ) } \\
{[2]}\end{array}$ & $\begin{array}{l}\text { - Asset } \\
\text { allotment } \\
\text { - Accessible } \\
\text { Without } \\
\text { internet (using } \\
\text { Intranet) }\end{array}$ & $\begin{array}{l}\text { Adminis- } \\
\text { trator }\end{array}$ & $\begin{array}{l}\text { - Less } \\
\text { modules in } \\
\text { terms of } \\
\text { Existing } \\
\text { problem } \\
\text { - Less } \\
\text { secure } \\
\text { - Has only } \\
\text { one Actor }\end{array}$ \\
\hline $\begin{array}{l}\text { (G. Rajkumar } \\
\text { and T. S. } \\
\text { Sundari)[5] }\end{array}$ & $\begin{array}{l}\text { - Biometric } \\
\text { Based } \\
\text { Authenticatio } \\
\mathrm{n} \\
\text { - SMS facility } \\
\text { to send } \\
\text { notification } \\
\text { and alerts }\end{array}$ & $\begin{array}{l}\text { - Student } \\
\text { - } \\
\text { Administ } \\
\text {-rator }\end{array}$ & $\begin{array}{l}\text { - Less } \\
\text { modules in } \\
\text { terms of } \\
\text { Existing } \\
\text { problem }\end{array}$ \\
\hline
\end{tabular}

\section{CONCLUSION}

In this document, it explains the idea about eHostel An android application for hostel management system. The application provides new platform for higher learning institution in managing hostel management system. In this research, we summarize different types of technologies which are used to 
develop such platform along with different features in terms of facilities provided by particular hardware as well as software. The main idea is to develop such application which overcome the problems caused by existing system by using latest technologies and provide ease to it's stack holders.

\section{REFERENCES}

[1]. R. K. Bista and A. J. Karki, "Hostel Management System", Vol. 2, No. 4, pp. 856-862, May-June, 2018, doi: 10.31142/ijtsrd14110, [Online]. Available:https://www.ijtsrd.com/listpapers/Hostel\%20Management\%20System

[2]. U. Elakkiya and P. Nirmala Priyadarshini, "Webbased Hostel management system for improving sustainable performance of educational institutions", Vol. 10, No. 1, pp. 050-053, doi: 10.21172/1.101.09, [Online]. Available: www.ijltet.org

[3]. Poojashree and A. Murthy, "Online Hostel Management", Vol. 5, No. 5, pp. 49-54, 2018, doi: 10.21276/ijcesr, [Online]. Available: www.troindia.in

[4]. S. Venkatesa Perumal, B.I. Juvanna, Sanju Rajan, “ Online Gate Pass Application Form For Hostel Students", Volume 119, No. 18 2018, 1657-1664, [Online]. Available: www.acadpubl.eu

[5]. G. Rajkumar and T. S. Sundari, "Hostel Management System Based on Finger Print Authentication", Vol. 11, No. 4, pp. 230-234, 2018, doi:10.13005/ojcst11.04.08, [Online].Available: https://www.researchgate.net/publi

[6]. cation/330537116_Hostel_Management_System_B ased_on_Finger_Print_Authentication

[7]. O. O. Adetunji, O. J. Akintunde and C. Otuneme, "Hostel Allocation System: Beyond the First Come First Serve Technique”, Vol. 18, No. 8, pp. 29-36, August, 2020, doi: 10.5281/zenodo.4012226, [Online]. Available: www.zenodo.org

[8]. M. Gaikwad, S. Wandale, S. Saoji, M. Ghode, S. Wadte, "Barcode based Student In Out System", Vol. 2, No. 2, pp. 776 -779, March-April, 2017, doi: 10.5281/zenodo.4012226, [Online]. Available: https://ijsrcseit.com/CSEIT1722248

[9]. M. F. B. M. Zin, "Enhanced Hostel Registration Application", Universiti Teknologi , Petronas, Malaysia, Rep. no. 13615, Date Accessed: 15/12/2020, [Online].

[10]. Available: http://utpedia.utp.edu.my/13621/

[11].S.Nale, D.Manhas, D.Gupta, "Android Based Hostel Security System Using QR Code: Survery", Vol. 7, No. 1, pp. 655 -658, March-April, 2017, [Online]. Available:

https://www.ijrar.org/papers/IJRAR2001661.pdf

[12].P. Aggarwal, A. Giri, "Cloud-Based, Smart Notice Delivery System Using OCR”, Jaypee University of Information Technology, Solan, Himachal Pradesh, India, Date Accessed: 17/12/2020, [Online]. Available:http://122.252.232.85:8080/jspui/bitstrea m/123456789/17477/1/SP13373_Pulkit\%20Aggarw al_Abhishek\%20Giri_CSE_2018.pdf

[13].T. Andhale, D. Divya, D. Sujata, K. Rnuka "Online Hostel Management", Vol. 5, No. 1, pp. 112-114, March, 2017, [Online]. Available: http://ijaes.co.in/wpcontent/uploads/2017/06/4.Online-HostelManagement.pdf

[14]. N. Illias, N. H. Abdul Hamid, Z. A. Shaffiei, "The Android Based Mobile Application To Manage Student Complaints", Vol. 9, No 3, June 2020, pp 1276 1283, doi: 10.11591/eei.v9.2065, [Online]. Available: www.beei.org

\section{Cite this article as :}

Kartik Chaudhri, Riddhi Kevat, "Study of Digitalized Hostel Management System", International Journal of Scientific Research in Computer Science, Engineering and Information Technology (IJSRCSEIT), ISSN : 2456-3307, Volume 7 Issue 2, pp. 366-371, MarchApril 2021. Available at

doi : https://doi.org/10.32628/CSEIT217280 Journal URL : https://ijsrcseit.com/CSEIT217280 